\title{
Sistem Pendukung Keputusan Pemilihan Wisata Kuliner Di Wilayah Kota Depok Menggunakan Metode Simple Additive Weighting (SAW)
}

\author{
Sunarti \\ Program Studi Sistem Informasi, Fakultas Teknik dan Informatika \\ Universitas Bina Sarana Informatika \\ Jakarta Barat, Indonesia \\ e-mail: sunarti.sni@bsi.ac.id
}

Diajukan: 11 Desember 2019; Direvisi: 29 Januari 2020; Diterima: 17 Februari 2020

\begin{abstract}
Abstrak
Wilayah kota Depok merupakan kota yang berkembang dari berbagai sektor. Salah satunya adalah sektor wisata kuliner. Wisata kuliner di wilayah kota Depok berkembang cukup pesat. Banyak tempat-tempat yang menjual berbagai jenis makanan, dari kaki lima sampai tempat modern. Banyaknya wisata kuliner di wilayah kota Depok menjadi masalah tersendiri dalam menentukan lokasi yang tepat untuk berkuliner. Dari banyaknya wisata kuliner, maka dibutuhkan suatu sistem pengambilan keputusan yang dapat membantu menentukannya. Dengan Simple Additive Weighting (SAW) menjadi sistem pengambilan keputusan pada permasalahan ini. Proses SAW dengan melakukan pencarian jumlah terbobot dari kinerja hasil proses penghitungan pada tiap alternatif. Kelebihan SAW menjadi pemecah permasalahan pemilihan wisata kuliner. Kriteria yang digunakan antara lain Lokasi, Harga, Transportasi, Jarak, Fasilitas, Parkir, Variasi Menu, dan Waktu Operasional. Alternatif lokasinya antara lain Pondok Laras, Mang Engking, Saung Talaga, Mang Kabayan, Warung SS Spesial, Daebak Fan Cafe, Soto Bu Tjondro, Warung Pasta Depok, Ayam Bakar Christina, Café Hello Bingsu, dan What's Up. Hasil dari penghitungan metode SAW diperoleh rekomendasi wisata kuliner di wilayah Depok adalah Warung Pasta Depok dengan nilai 0,93.
\end{abstract}

Kata kunci: Sistem pengambilan keputusan, SAW, Wisata kuliner.

\begin{abstract}
Depok City area is a city that is developing from various sectors. One of them is the culinary tourism sector. Culinary tourism in the city of Depok is developing quite rapidly. Many places that sell various types of food, from street vendors to modern places. The number of culinary tours in the city of Depok becomes a problem in determining the right location for culinary. Of the many culinary tours, we need a decision-making system that can help determine it. With Simple Additive Weighting (SAW) a decision-making system on this problem. SAW the process by searching for a weighted amount of the results of the calculation process in each alternative. The advantage of SAW is a problem solver for culinary tourism selection. The criteria used include Location, Price, Transportation, Distance, Facilities, Parking, Menu Variation and Operating Time. Alternative locations include Pondok Laras, Mang Engking, Saung Talaga, Mang Kabayan, Warung SS Special, Daebak Fan Cafe, Soto Bu Tjondro, Warung Pasta Depok, Roast Chicken Christina, Cafe Hello Bingsu and What's Up. The results of the calculation of the SAW method obtained culinary tourism recommendations in the Depok area are Warung Pasta Depok with a value of 0.93 .
\end{abstract}

Keywords: Decision making system, SAW, Culinary tourism.

\section{Pendahuluan}

Makanan dan kesehatan perihal utama dalam hidup. Tanpa makan bisa mengakibatkan tidak akan dapat menjalankan kehidupan. Makanan sebagai sumber kehidupan, tetapi makanan juga dapat mengakibatkan orang menjadi tidak sehat. Dengan hal tersebut sebagai makhluk hidup membutuhkan asupan makanan sehat untuk menjadikan hidup menjadi sehat dan bahagia [1]. Menurut undang-undang No. 10 Tahun 2009 Pasal 14 Ayat 1 dijelaskan jasa makanan dan minuman merupakan salah satu usaha 
pariwisata [2]. Saat ini wisata kuliner menjadi incaran pada tiap orang saat berkunjung ke suatu daerah. Alasannya karena para pendatang merasa penasaran pada menu khas pada daerah tersebut. Wisata kuliner menjadi alternatif yang dapat menunjang potensi berbagai wisata antara lain alam, budaya, dan sejarah [3]. Semboyan kota Depok "Depok a Friendly City" pemerintah menciptakan para wisatawan sebagai sahabat saat datang ke kota Depok merasakan rasa nyaman dan unggul pada aspek wisata [4]. Ketidaktahuan informasi pada lokasi wisata kuliner yang ada akan mengakibatkan permasalahan bagi wisatawan yang ingin berkuliner [5]. Wisata kuliner kota Depok memiliki banyak pilihan makanan dari kaki lima hingga lokasi yang modern. Berbagai jenis makanan tersedia. Makanan tersedia dengan banyak varian, lokasi sehingga mengakibatkan rasa bingung untuk memilih lokasi tujuan kulinernya [4].

Penelitian yang dilakukan untuk penentuan wisata kuliner diwilayah Depok, memiliki beberapa tolok ukur yang menjadi acuan. Untuk kriteria yang digunakan terdiri dari: Lokasi, Harga, Transportasi, Jarak, Fasilitas, Parkir, Variasi Menu, dan Waktu Operasional. Alternatif lokasi yang menjadi penilaian antara lain: Pondok Laras, Mang Engking, Saung Talaga, Mang Kabayan, Warung Pasta Depok, Daebak Fan Cafe, Soto Bu Tjondro, Warung SS Spesial, Ayam Bakar Christina, Café Hello Bingsu, dan What's Up. Penelitian ini penulis menggunakan sistem penunjang keputusan dengan metode Simple Additive Weighting (SAW). Di mana metode yang digunakan ini akan dapat menetapkan nilai terbobot pada tiap field. Pada tiap field mengikuti peringkat alternatif pemilihan yang berdasarkan bobot untuk mendapatkan hasil yang lebih akurat [6]. Metode SAW merupakan sebuah metode untuk pengambilan keputusan dan metode ini bisa menyelesaikan untuk data cost dan benefit dengan serentak [7]. Metode SAW ini dimanfaatkan dalam proses pemberian peringkat sebuah data dengan cara memanfaatkan value preferensi [8]. Pada metode SAW dapat menjumlahkan dengan melakukan pencarian data terbobot dari kinerja pada tiap alternatif [9]. SAW memiliki konsep yang sederhana, tidak menyulitkan, mudah untuk dipahami, dan memiliki kemampuan pengukuran kinerja relatif dari alternatif yang ada [10]. Tujuan dari penelitian ini adalah mengetahui lokasi kuliner yang dapat dijadikan pemilihan yang tepat bagi peminat kuliner di wilayah Kota Depok. Metode SAW yang digunakan dapat memberikan pemilihan wisata kuliner berdasarkan value terbobot pada atribut yang diperlukan [6].

\section{Metode Penelitian}

\subsection{Pengambilan Keputusan dengan Simple Additive Weighting (SAW)}

Permasalahan wisata kuliner di wilayah Kota Depok perlu mendapatkan perhatian saat ini. Pada penelitian ini penulis menyelesaikan permasalahan menggunakan Simple Additive Weighting (SAW). SAW dilakukan dengan cara menjumlahkan skor bobot. Selain itu SAW dapat memecahkan perkiraan skor terbobot dari rating kemampuan di setiap preferensi pada semua field. Tingkatan untuk menyelesaikan metode ini dengan cara, antara lain [11]:

a. Menetapkan jenis-jenis kriteria untuk kebutuhan referensi sebagai pengambilan keputusan, yaitu $C_{j}$.

b. Pengelompokan/pengklasifikasi untuk skor yang digunakan pada tiap alternatif $A_{i}$ pada tiap kriteria yang telah ditetapkan, di mana skor didapatkan berasal dari skor crips.

c. Melakukan penetapan pada skor rating dengan menyesuaikan pada tiap alternatif ke kriteria kemudian melakukan pemodelan pada bilangan fuzzy dan selanjutnya dilakukan konversi pada bilangan crips.

d. Melakukan penjelasan pada skor terbobot preference ataupun bisa juga merujuk pada fase kebutuhan (W) pada tiap tolok ukur yang digunakan.

e. Membuat matriks keputusan (X) dan membentuk beberapa daftar yang ada dengan melakukan penyesuaian di tiap pilihan pada tolok ukur yang ada.

f. Membuat bentuk data menjadi ternormalisasi paradigma hasil dengan cara melakukan langkah-langkah pelaksanaan estimasi value dari kemampuan data yang ternormalisasikan $\left(r_{i j}\right)$ dari tiap pilihan $A_{i}$ pada tolok ukur $C_{j}$.

$$
R_{i j}=\begin{aligned}
& \frac{X_{i j}}{\text { MaxXij }} \text { Jika } j \text { adalah atribut keuntungan (benefit) } \\
& \frac{\text { MinX } X_{i j}}{X_{i j}} \text { jika } j \text { adalah atribut keuntungan (cost) } X_{i j}
\end{aligned}
$$

Uraiannya:

$\mathrm{R}_{\mathrm{ij}} \quad=$ Rating pada kerja ternormalisasikan

$\operatorname{MaxX}_{\mathrm{ij}}=$ Skor termaksimal pada tiap baris dan kolom 
$\operatorname{Min}_{\mathrm{ij}}=$ Skor terminim pada tiap baris dan kolom

$\mathrm{X}_{\mathrm{ij}} \quad=$ Baris dan kolom dari matriks

Keterangan :

1. Kriteria untuk pengambilan keputusan akan diberikan skor keuntungan jika memperoleh keuntungan, sedangkan pada kriteria biaya pengambilan keputusan akan ada jika ada biaya yang diperlukan.

2. Jika kriteria keuntungan pada skor dilakukan proses bagi pada skor di tiap kolom, tetapi pada kriteria biaya, skor dari setiap kolom dilakukan proses bagi dengan skor.

a. Proses perhitungan skor rating kinerja ternomalisasi $\left(r_{i j}\right)$ akan menciptakan matriks ternormalisasi $(R)$

b. Proses perhitungan skor preferensi $\left(V_{i}\right)$ didapat pada proses penjumlahan dari perkalian elemen kerja matriks teromalisasi bersama bobot preferensi $(W)$ yang bersesuaian elemen kolom matriks $(W)$.

$$
V_{i}=\sum_{j=1}^{n} W_{j} r_{i j}
$$

Uraiannya:

$\mathrm{V}_{\mathrm{i}} \quad=$ Ranking pada tiap-tiap pilihan

$\mathrm{W}_{\mathrm{j}} \quad=$ Skor bobot ranking (pada tiap-tiap pilihan)

$\mathrm{r}_{\mathrm{ij}} \quad=$ Skor rating kinerja ternormalisasikan

Skor $V_{i}$ yang lebih besar menunjukkan pada pilihan $A_{i}$ yang lebih terpilih [11].

\subsection{Variabel dan Pengukuran}

a. Variabel Alternatif $\left(\boldsymbol{A}_{i}\right)$

Penelitian ini yang akan dijadikan pilihan sebagai alternatif kuliner di wilayah Kota Depok yaitu: Pondok Laras, Mang Engking, Saung Talaga, Mang Kabayan, Warung SS Spesial, Daebak Fan Cafe, Soto Bu Tjondro, Warung Pasta Depok, Ayam Bakar Christina, Café Hello Bingsu, dan What's Up.

b. Variabel Kriteria $\left(\boldsymbol{C}_{j}\right)$

Untuk kriteria yang dibutuhkan pada penelitian ini yaitu: Lokasi, Harga, Transportasi, Jarak, Fasilitas, Parkir, Variasi Menu, dan Waktu Operasional. Kuesioner digunakan sebagai tolok ukur tercapainya penelitian ini. Informan untuk pengisian kuesioner dengan sasarannya adalah, mahasiswa, anak muda, orang setengah baya, dan para tetua sebagai penyuka kuliner. Pada pengisian kuesioner penggambarannya adalah usia, jenis kelamin, pendidikan, pekerjaan, dan isian kuesioner untuk penelitian ini.

\subsection{Tingkatan Penelitian}

Tingkatan penelitian pemilihan wisata kuliner wilayah kota Depok ada 2 langkah, yaitu pengumpulan data dan analisis data.

\section{a. Pengumpulan Data}

Pengumpulan data pada permasalahan pemilihan wisata kuliner ada bagian-bagian yang akan dibuat antara lain dengan cara: (1) Data Primer dilaksanakan melalui (a) Studi Pustaka, yang dilakukan penulis antara lain dengan melakukan pengumpulan beberapa buku dan mempelajari buku-buku tersebut, artikel/penulisan ilmiah dan literature-literature berlandaskan pada permasalahan yang sudah pernah dilakukan sebelumnya untuk dijadikan kajian yang mendukung pembahasan permasalahan. (b) Pengamatan, pada langkah ini melakukan pengamatan secara langsung pada tempat kuliner diwilayah Depok, selanjutnya peneliti melakukan pengolahan data daripada hasil pengamatan, dari hasil olahan yang sudah diperoleh berupa data dilanjutkan dengan melakukan proses penghitungan menggunakan metode SAW; (2) Data sekunder didapatkan dengan melakukan mengumpulkan data, mengklarifikasikan lanjut pada jenjang penghitungan skor melalui pendataan tertulis.

\section{b. Menganalisis Data}

Pada proses menganalisis sebuah data sudah dibuatkan yaitu suatu hal paling berharga dalam sebuah metodologi pengkajian. Untuk menganalisis, maka dilakukan proses pengolahan data dan diberikan arti serta makna untuk menyelesaikan dari permasalahan yang ada. Pembahasan analisis mengenai pemilihan kuliner wisata kuliner wilayah kota Depok dilakukan dengan SAW. Di mana SAW ini ialah metode pengambilan keputusan dengan memperhatikan pada setiap hal data kualitatif dan kuantitatif. Pada pembahasan mengenai pemilihan wisata kuliner wilayah Depok yang digunakan adalah data kuantitatif. 


\subsection{Teknik Analisis Data}

Pada pengkajian permasalahan pemilihan wisata kuliner ini cara menganalisis antara lain dengan menggunakan algoritma SAW. Pada Teknik menganalisis data ini metode akan dilakukan dengan analisis data untuk pemilihan wisata kuliner di wilayah kota Depok. Cara melakukan penganalisisan data penelitian ini memakai data kuantitatif, antara lain menganalisis data memakai konvensi ilmu hitung pada data skor/numeric.

\section{Hasil dan Pembahasan}

Pembahasan mengenai permasalahan wisata kuliner diwilayah kota Depok menggunakan sistem pengambilan keputusan yaitu metode SAW. Pemecah masalah yang ada, digunakan untuk memutuskan pemilihan wisata kuliner terbaik adalah SAW. Hasil dari proses perhitungan pada SAW ini menunjukkan lokasi kuliner yang paling diminati oleh pengunjung atau penikmat wisata kuliner diwilayah kota Depok yang akan dijadikan rekomendasi untuk berkuliner.

\subsection{Penentuan alternatif dan kriteria yang digunakan}

Pemantapan pemilihan wisata kuliner wilayah Depok, beberapa kriteria yang merupakan rujukan untuk dijadikan proses hasil dengan menggunakan metode SAW. Untuk kriteria yang ditetapkan di antaranya adalah Q1=lokasi, Q2=harga, Q3=transportasi, Q4=jarak, Q5= fasilitas, Q6=parkir, Q7= variasi menu, dan Q8=waktu operasional. Alternatif penilaian di antaranya P1=Pondok Laras, P2=Mang Engking, P3= Saung Talaga, P4=Mang Kabayan, P5= Warung SS Spesial, P6=Daebak Fan Cafe, P7=Soto Bu Tjondro, P8= Warung Pasta Depok, P9=Ayam Bakar Christina, P10=Café Hello Bingsu, dan P11=What's Up.

\subsection{Algoritma Simple Additive Weighting (SAW)}

Prosedur utama untuk SAW mensyaratkan skor kriteria $C_{j}$ pada suatu set alternatif $A_{i}$, bobot preferensi $\left(W_{j}\right)$ untuk tiap kriteria $C_{j}$. Untuk menentukan nilai bobot dari kriteria yang digunakan pada Tabel 1 sebagai berikut:

Tabel 1. Kriteria penilaian.

\begin{tabular}{ccc}
\hline Kode & Kriteria & Bobot \\
\hline Q1 & Lokasi & $15 \%$ \\
\hline Q2 & Harga & $20 \%$ \\
\hline Q3 & Transportasi & $10 \%$ \\
\hline Q4 & Jarak & $10 \%$ \\
\hline Q5 & Fasilitas & $10 \%$ \\
\hline Q6 & Parkir & $10 \%$ \\
\hline Q7 & Variasi Menu & $15 \%$ \\
\hline Q8 & waktu operasional & $10 \%$ \\
\hline
\end{tabular}

Pada Tabel 2 dijelaskan standar nilai dari Algoritma SAW, untuk range penilaian 1 sampai dengan 5, dapat dilihat sebagai berikut:

Tabel 2. Standar nilai algoritma SAW.

\begin{tabular}{ccc}
\hline Nilai & Keterangan & Bobot \\
\hline 1 & Sangat Rendah & 0.2 \\
\hline 2 & Rendah & 4 \\
\hline 3 & Cukup & 0.6 \\
\hline 4 & Tinggi & 0.8 \\
\hline 5 & Sangat Tinggi & 1 \\
\hline
\end{tabular}

Tabel 3 berikut adalah rating kecocokan dari setiap alternatif pada setiap kriteria dalam penentuan wisata kuliner di wilayah kota Depok.

Tabel 3. Hasil nilai setiap alternatif pada setiap kriteria.

\begin{tabular}{ccccccccc}
\hline Alternatif & Q1 & Q2 & Q3 & Q4 & Q5 & Q6 & Q7 & Q8 \\
\hline P1 & 0,8 & 1 & 0,8 & 0,6 & 1 & 1 & 0,6 & 0,6 \\
\hline P2 & 0,6 & 1 & 0,6 & 0,6 & 1 & 1 & 0,6 & 0,6 \\
\hline P3 & 0,6 & 1 & 0,8 & 0,8 & 1 & 1 & 0,8 & 0,8 \\
\hline
\end{tabular}




\begin{tabular}{ccccccccc}
\hline Alternatif & Q1 & Q2 & Q3 & Q4 & Q5 & Q6 & Q7 & Q8 \\
\hline P4 & 0,8 & 1 & 0,8 & 0,8 & 1 & 1 & 1 & 0,6 \\
\hline P5 & 0,8 & 1 & 1 & 1 & 1 & 1 & 1 & 0,8 \\
\hline P6 & 0,8 & 1 & 1 & 0,6 & 1 & 1 & 1 & 0,6 \\
\hline P7 & 0,6 & 1 & 1 & 0,6 & 1 & 1 & 0,6 & 0,6 \\
\hline P8 & 0,6 & 1 & 0,8 & 0,8 & 1 & 1 & 0,8 & 0,8 \\
\hline P9 & 0,8 & 1 & 0,8 & 0,8 & 1 & 1 & 1 & 0,6 \\
\hline P10 & 0,8 & 1 & 0,8 & 1 & 1 & 1 & 0,8 & 0,8 \\
\hline P11 & 0,6 & 1 & 0,6 & 0,6 & 1 & 1 & 0,6 & 0,6 \\
\hline
\end{tabular}

Membuat Matriks keputusan berdasarkan kriteria (Ci), di mana $X_{i j}$ merupakan rating kinerja alternatif ke- $i$ terhadap atribut, sehingga diperoleh matriks sebagai berikut:

Matriks $\quad\left(\begin{array}{cccccccc}1 & 0,6 & 0,8 & 0,8 & 0,8 & 0,8 & 0,8 & 0,8 \\ 0,8 & 1 & 0,8 & 0,8 & 1 & 1 & 0,8 & 1 \\ 1 & 0,8 & 0,6 & 1 & 0,8 & 0,8 & 1 & 0,8 \\ 0,8 & 0,6 & 0,8 & 0,6 & 0,8 & 0,8 & 0,8 & 0,6 \\ 0,8 & 0,75 & 0,75 & 1 & 0,6 & 1 & 0,6 & 1 \\ 1 & 1 & 1 & 0,8 & 0,8 & 0,8 & 0,8 & 0,8 \\ 0,6 & 0,6 & 0,8 & 0,6 & 1 & 0,6 & 0,8 & 1 \\ 1 & 1 & 1 & 1 & 1 & 1 & 1 & 0,8 \\ 1 & 0,6 & 0,6 & 0,8 & 0,8 & 0,6 & 0,6 & 0,6 \\ 0,8 & 0,6 & 0,75 & 0,8 & 0,8 & 1 & 0,8 & 1 \\ 1 & 0,75 & 0,75 & 0,8 & 1 & 1 & 1 & 1\end{array}\right)$

Normalisasi matriks, dari perhitungan matriks normalisasi $R$ dapat diperoleh matriks ternormalisasi R, sebagai berikut:

Matriks $\left.\begin{array}{rrrrrrrr}1 & 1 & 0,8 & 0,8 & 0,8 & 0,8 & 0,8 & 0,8 \\ 0,8 & 0,8 & 0,8 & 0,8 & 1 & 1 & 0,8 & 1 \\ 0,8 & 0,6 & 0,6 & 1 & 0,8 & 0,8 & 1 & 0,8 \\ 1 & 0,75 & 0,8 & 0,6 & 0,8 & 0,8 & 0,8 & 0,6 \\ 0,6 & 1 & 0,75 & 1 & 0,6 & 1 & 0,6 & 1 \\ 1 & 0,6 & 1 & 0,8 & 0,8 & 0,8 & 0,8 & 0,8 \\ 1 & 1 & 0,8 & 0,6 & 1 & 0,6 & 0,8 & 1 \\ 0,8 & 0,6 & 1 & 1 & 1 & 1 & 1 & 0,8 \\ 1 & 0,6 & 0,6 & 0,8 & 0,8 & 0,6 & 0,6 & 0,6 \\ & 0,75 & 0,75 & 0,8 & 0,8 & 1 & 0,8 & 1 \\ & & 0,75 & 0,8 & 1 & 1 & 1 & 1\end{array}\right)$

Menentukan rangking, sesudah melakukan proses normalisasi, selanjutnya ada proses hitung pada nilai preferensi tiap alternatif $\left(V_{i}\right)$ dengan vector bobot $W$ yang telah diberikan oleh pengambilan keputusan, dan penghitungannya menghasilkan seperti Tabel 4 berikut ini:

Tabel 4. Angka preferensi dan rank.

\begin{tabular}{ccc}
\hline Alternatif & Hasil & Rank \\
\hline P1 & 0,79 & 8 \\
\hline P2 & 0,9 & 3 \\
\hline P3 & 0,86 & 6 \\
\hline P4 & 0,72 & 10 \\
\hline P5 & 0,8 & 11 \\
\hline P6 & 0,89 & 5 \\
\hline P7 & 0,73 & 7 \\
\hline P8 & 0,98 & 1 \\
\hline P9 & 0,7 & 9 \\
\hline P10 & 0,8 & 4 \\
\hline P11 & 0,91 & 2 \\
\hline
\end{tabular}

Proses akhir dari penghitungan algoritma SAW $V_{i}$ pada tiap alternative yang ada, dapat disimpulkan bahwa proses penghitungan yang telah dilaksanakan maka menghasilkan skor tertinggi adalah 
kode (P8) dengan nilai 0,98 yaitu Warung Pasta Depok. Nilai tersebut merupakan proses perhitungan tertinggi yang dijadikan rekomendasi sebagai lokasi pemilihan wisata kuliner di wilayah kota Depok.

\section{Kesimpulan}

Wisata kuliner diwilayah kota Depok sangat beragam. Banyak sekali penikmat kuliner yang ingin berkuliner pada wilayah tersebut. Metode SAW melakukan penghitungan berdasarkan alternatif dan kriteria yang ada. Hasil dari penghitungannya diperoleh nilai 0,98 yaitu Warung Pasta Depok hasil penghitungan tertinggi yang dijadikan tempat wisata kuliner wilayah kota Depok. Metode SAW untuk proses hitungnya bisa menyelesaikan permasalahan pemilihan wisata kuliner. Proses hitungnya dari beberapa pilihan dan tolok ukur yang menjadi ketetapannya. Proses beban tiap tolok ukur menguraikan faktor manfaat untuk algoritma SAW. Untuk pemecah masalah lanjutan gunakan metode yang berbeda dengan penambahan kriteria dan alternatif. Bisa juga dengan melakukan komparasi metode sistem penunjang keputusan lainnya.

\section{Daftar Pustaka}

[1] F. D. Sawel, A. A. E. Sawel, and M. D. P. Sinsuw, "Sistem Pendukung Keputusan Rekomendasi Makanan Khas Sulawesi Utara yang Menunjang Diet," Jurnal Teknik Informatika, vol. 9, no. 1, 2016, doi: 10.35793/jti.9.1.2016.13485.

[2] Keputusan Presiden Republik Indonesia Nomor 99 Tahun 1998, "Undang Undang Tentang Kepariwisataan," 1998.

[3] E. Besra, "Potensi Wisata Kuliner Dalam Mendukung Pariwisata Di Kota Padang," urnal Riset Akuntansi dan Bisnis, vol. 12, pp. 74-101, 2012.

[4] A. Indarwasti, Barizana SA, and Prottasof G Kodu, "Sistem Pendukung Keputusan Pemilihan Tempat Kuliner di Depok dengan Topsis," Multinetics,vol. 3, no. 1, p. 27, 2017, doi: 10.32722/vol3.no1.2017.pp27-31.

[5] M. G. Resmi and D. Irmayanti, "Metode Simple Additive Weighting Dalam Sistem Pendukung Keputusan Pemilihan Tempat Kuliner Di Kabupaten Purwakarta," Piksel Penelitian Ilmu Komputer Sistem Embeded Logic, vol. 7, no. 1, pp. 23-32, 2019, doi: 10.33558/piksel.v7i1.1661.

[6] W. Supriyanti, "Rancang Bangun Aplikasi Sistem Pendukung Keputusan Penerima Beasiswa dengan Metode SAW," Creative Information Technology Journal, vol. 1, no. 1, p. 67, 2015, doi: 10.24076/citec.2013v1i1.11.

[7] H. Jayawardana, "Pemilihan Rumah Makan Di Kota Merauke Berbasis Sample Additive Weighting (Saw)," Musamus Journal Of Technology \& Information (MJTI), vol. 01, no. 02, pp. 47-50, 2019.

[8] N. D. Saksono, Y. A. Sari, and R. K. Dewi, "Rekomendasi Lokasi Wisata Kuliner Menggunakan Metode K-Means Clustering Dan Simple Additive Weighting," Jurnal Pengembangan Teknologi Informasi dan Ilmu Komputer. Univ. Brawijaya, vol. 2, no. 10, pp. 3835-3842, 2018.

[9] A. Hidayat, Muhamad Muslihudin, and Indah Tri Utami, "Sistem Pendukung Keputusan Menentukan Lokasi Cafe Baru Suncafe Sebagai Destinasi Wisata Kuliner Di Kabupaten Pringsewu Menggunakan Metode Simple Additive Weighting (SAW)," Jurnal TAM (Technol. Accept. Model), vol. 6, no. 1, pp. 71-79, 2016.

[10] S. Sunarti, "Perbandingan Metode Topsis dan Saw Untuk Pemilihan Rumah Tinggal," Journal of Information System, vol. 3, no. 1, pp. 69-79, 2018.

[11] D. Nofriansyah, Konsep Data Mining Vs Sistem Pendukung Keputusan. Yogyakarta: Deepublish, 2015. 